\title{
STRATEGI PENGELOLAAN AIR LIMBAH SENTRA UMKM BATIK YANG BERKELANJUTAN DI KABUPATEN SUKOHARJO
}

\author{
M. Wawan Kurniawan(1), P. Purwanto(1,2) S. Sudarno(1,3) \\ (1) Program Magister Ilmu Lingkungan, UNDIP, Semarang \\ (2)Jurusan Teknik Kimia, Fakultas Teknik,UNDIP, Semarang \\ (3)Jurusan Teknik Lingkungan, Fakultas Teknik, UNDIP, Semarang \\ Email : mw kurniawan@yahoo.co.id
}

\begin{abstract}
ABSTRAK
Industri batik menimbulkan dampak air limbah organik dalam jumlah yang besar, warna yang pekat, berbau menyengat dan memiliki suhu, keasaman (pH), Biochemical Oxygen Demand (BOD), Chemical Oxygen Demand (COD) serta Total Suspended Solid (TSS) yang tinggi. Desa Banaran Kecamatan Grogol Kabupaten Sukoharjo merupakan sentra industri usaha mikro, kecil dan menengah (UMKM) batik yang potensial dalam mendukung perekonomian lokal namun belum memiliki sistem pengelolaan air limbah. Penelitian ini bertujuan untuk menyusun strategi pengelolaan air limbah UMKM Batik di Desa Banaran dalam perspektif good governance berdasarkan kajian aspek teknis, aspek ekonomi, aspek manajemen dan aspek sosial dengan menggunakan analisis SWOT (Strength, Weakness, Opportunity and Threats) dilanjutkan penentuan prioritas strategi dengan metode AHP (Analytical Hierarchy Process). Untuk mengkaji keempat aspek tersebut maka dilakukan observasi, dokumentasi, pengukuran, uji laboratorium di lokasi penelitian dan wawancara terhadap stakeholders dalam pengelolaan air limbah UMKM Batik di Desa Banaran yaitu pemerintah daerah, UMKM Batik, tokoh masyarakat dan sektor swasta pelaku Corporate Social Responsibility (CSR) di Kabupaten Sukoharjo. Berdasarkan hasil analisis SWOT dan metode AHP menghasilkan prioritas strategi untuk mewujudkan pengelolaan air limbah UMKM Batik yaitu : (1) Aspek Manajemen : penyusunan kebijakan dan program pengelolaan air limbah UMKM Batik, (2) Aspek Teknis : penentuan lahan untuk Instalasi Pengolahan Air Limbah (IPAL) yang representatif, (3) Aspek Ekonomi : swadana UMKM Batik dalam operasional dan perawatan IPAL dan (4) Aspek Sosial : pembinaan teknis kepada UMKM Batik dalam pengelolaan air limbah. Untuk mewujudkan pengelolaan air limbah UMKM Batik secara optimal dan berkelanjutan diperlukan kerjasama dan kemitraan yang baik di antara stakeholders sebagai perwujudan dari paradigma good governance didalam kerangka pembangunan yang berkelanjutan.
\end{abstract}

Kata kunci : pengelolaan air limbah UMKM batik, good governance, prioritas strategi

\section{ABSTRACT}

Batik industry impacts in the form of organic wastewater in large amount, dense color, odor and has a high temperature, acidity (pH), Biochemical Oxygen Demand (BOD), Chemical Oxygen Demand (COD) and Total Suspended Solid (TSS). Banaran village Grogol Sukoharjo is potentially industrial district of micro, small and medium enterprises (SMEs) batik in supporting the local economy, but has not had a waste water treatment system. This study aimed to develop wastewater management strategy in SMEs Batik Banaran village in the perspective of good governance based on a review of technical aspects, economic aspects, management aspects and social aspects with the SWOT analysis (Strength, Weakness, Opportunity and Threats) continued prioritization strategy with AHP (Analytical Hierarchy Process). To examine these four aspects of the observations, documentation, measurement, laboratory tests at study sites and interviews with stakeholders in waste water management in SMEs Batik Village Banaran ie local governments, SMEs Batik, community leaders and private sector actors Corporate Social Responsibility (CSR) in Sukoharjo. Based on the results of the SWOT analysis and strategic priorities with the AHP method generates wastewater realize SMEs Batik namely: (1) Management aspects: development of policies 
and programs of SMEs Batik wastewater management, (2) Technical aspects: the determination of representative land for the Waste Water Treatment Plant (WWTP), (3) Economic aspects: self-help SMEs Batik in WWTP operation and maintenance, and (4) Social aspects: technical assistance to SMEs Batik in wastewater management. To realize SMEs Batik wastewater treatment optimally and required ongoing good cooperation and partnership among stakeholders as a manifestation of a paradigm of good governance within the framework of sustainable development.

Keywords : batik SMEs wastewater management, good governance, strategic priorities

\section{PENDAHULUAN}

Industri batik menimbulkan dampak berupa limbah cair organik dengan volume yang besar, warna yang pekat, berbau menyengat dan memiliki suhu, keasamam $(\mathrm{pH})$, Biochemical Oxygen Demand (BOD), Chemical Oxygen Demand (COD), Total Suspended Solid (TSS) yang tinggi. Hal ini disebabkan oleh penggunaan bahan-bahan kimia dan zat warnadalam proses produksi batik. Bahan kimia yang digunakan antara lain Soda Kostik $(\mathrm{NaOH})$, Soda $\mathrm{Abu}\left(\mathrm{Na}_{2} \mathrm{CO}_{3}\right)$, Soda Kue $\left(\mathrm{NaHCO}_{3}\right)$, Asam Sulfat $\left(\mathrm{H}_{2} \mathrm{SO}_{4}\right)$, Sulfid, Nitrit dan Teepol, sedangkan zat warna yang digunakan antara lain zat warna asam, zat warna basa, zat warna direk, zat warna reaktif, zat warna naftol dan zat warna bejana.

Apabila air limbah dibuang ke media lingkungan tanpa diolah terlebih dahulu maka dapat menyebabkan pencemaran lingkungan terutama ekosistem perairan. Suhu yang tinggi akan mengakibatkan kandungan oksigen terlarut atau Dissolved Oxygen (DO) dalam air menurun yang akan membunuh organisme sehingga mengganggu keseimbangan ekosistem air. Selain itu limbah organik akan meningkatkan kadar nitrogen menjadi senyawa nitrat yang menyebabkan bau busuk (Sastrawijaya, 2009).

Desa Banaran Kecamatan Grogol Kabupaten Sukoharjo merupakan sentra UMKM Batik yang potensial dalam mendukung pertumbuhan perekonomian lokal namun belum memiliki sistem pengelolaan air limbah dalam proses produksinya. Air limbah dibuang ke saluran drainase umum bercampur dengan air limbah domestik menuju Sungai Jenes yang berbatasan langsungdengan sentra UMKM Batik Laweyan Surakarta. Isu lingkungan mengenai pencemaran sungai akibat limbah cair dari proses produksi batik di Desa Banaran banyak dimuat di media massa baik lokal maupun nasional, salah satunya adalah di surat kabar Harian Solo Pos pada tanggal 16 Januari 2013 yang memuat berita tentang sentra UMKM Batik di Desa Banaran Kecamatan Grogol Kabupaten Sukoharjo yang belum memiliki Instalasi Pengolahan Air Limbah (IPAL) dan membuang air limbah ke Sungai Jenes tanpa diolah terlebih dahulu.

Pengelolaan air limbah UMKM Batik yang baik di Desa Banaran tidak bisa terlepas dari tata kelola pemerintahan yang baik (good governance). Terdapat berbagai definisi good governance antara lain menurut World Bank yaitu penyelenggaraan manajemen pembangunan yang solid dan bertanggungjawab, sejalan dengan demokrasi dan pasar efisien, penghindaran salah alokasi dana investasi dan anggaran, serta penciptaan kerangka hukum dan politik bagi tumbuhnya aktivitas kewiraswastaan, sedangkan UNDP mendefinisikan good governance sebagai hubungan yang sinergis dan konstruktif diantara negara, sektor swasta dan masyarakat.UNDP mensyaratkan 11 karakteristik good governance yaitu adanya partisipasi masyarakat, penegakan hukum, transparansi, kesetaraan, daya tanggap pemerintah, wawasan ke masa depan, akuntabilitas, pengawasan, efisiensi dan efektivitas, profesionalisme dan berorientasi pada konsensus.

Good governancedalam iklim demokrasi dan era otonomi daerah menuntut adanya desentralisasi dan dekonsentrasi kewenangan dari pemerintah pusat ke pemerintah daerah dengan harapan penyelenggaraan pemerintahan lebih fleksibel, responsif, efisien, efektif, inovatif dan mampu menumbuhkan peran serta masyarakat. 
Good governance sebagaimana dirumuskan oleh Indonesian Centre for Environmental Law (ICEL) mempersyaratkan lima hal, yaitu : (1) Lembaga perwakilan yang mampu menjalankan fungsi kontrol dan penyalur aspirasi masyarakat, (2) Pengadilan yang mandiri, bersih dan profesional, (3) Birokrasi yang responsive terhadap kebutuhan masyarakat dan memiliki integritas, (4) Masyarakat sipil yang kuat sehingga mampu melaksanakan fungsi kontrol, (5) Desentralisasi dan lembaga perwakilan yang kuat (Hadi, 2005). Dalam kerangka pembangunan yang berkelanjutan yang mengintegrasikan aspek ekonomi, sosial dan lingkungan, maka konsep good governance dalam implementasinya berkembang menjadi good environmental governance, good corporate governance dan good social governance.

Penelitian ini bertujuan untuk menyusun strategi pengelolaan air limbah UMKM Batikyang optimal dan berkelanjutan di Desa Banaran Kecamatan Grogol Kabupaten Sukoharjo berdasarkan kajian aspek teknis, aspek ekonomi, aspek manajemen dan aspek sosial.

\section{METODOLOGI}

Pendekatan metode penelitian yang diterapkan adalah pendekatan deskriptif kualitatif meliputi kajian variabel aspek teknis, aspek manajemen dan aspek sosial dan penentuan strategi dengan analisis Strength, Weakness, Opportunity dan Threat (SWOT) dan penentuan prioritas strategi dengan metode Analytical Hierarchy Process (AHP).

Kajian variabel aspek teknis mencakup indikator yaitu (a) kondisi teknis wilayah, (b) beban pencemaran air limbah dan (c) penentuan sistem dan teknologi IPAL. Pada variabel ekonomi dikaji indikator yaitu (a) kondisi ekonomi wilayah, (b) biaya investasi, operasional dan perawatan IPAL, (c) program CSR swasta. Pada aspek manajemen dikaji indikator antara lain(a) regulasi, kebijakan dan program pemerintah, (b) kelembagaan pemerintah, (c) kelembagaan UMKM dan, sedangkan kajian pada aspek sosial 64 mencakup variabel (a) persepsi UMKM Batik, (b) sikap UMKM Batik, dan (c) partisipasi UMKM Batik.

Penelitian dilaksanakan dengan melakukan pengukuran, uji laboratorium, observasi dan wawancara di lokasi penelitian dan terhadap stakeholders dalam pengelolaan air limbah UMKM Batik di Kabupaten Sukoharjo yaitu pemerintah daerah, UMKM Batik, tokoh masyarakat dan sektor swasta pelaku Corporate Social Responsibility (CSR) di Desa Banaran.

Kualitas dan kuantitas air limbah batik dan badan air diteliti dengan melakukan uji laboratorium dan pengukuran debit aliran air limbah batik jenis cap/tulis dan jenis printing air limbah serta saluran drainase air limbah dan Sungai Jenes di upstream dan downstream di Desa Banaran. Dengan mengetahui kualitas dan kuantitas air limbah maka dapat diketahui beban pencemaran untuk perencanaan Instalasi Pengolahan Air Limbah (IPAL) dan pengendalian pencemaran air dan sungai.

Responden UMKM Batik diambil secara purposive sampling terhadap 20 UMKM Batik.

Berdasarkan hasil kajian dari variabel aspek teknis, aspek manajemen dan aspek sosial maka dapat dirumuskan alternatif strategi menggunakan analisis SWOT secara kualitatif dengan mengidentifikasi kekuatan dan kelemahan dari faktor internal serta peluang dan ancaman dari faktor eksternal. Selanjutnya dilakukan penentuan prioritas dari alternatif strategi hasil analisis SWOT melalui penilaian dari keypersons yang mewakili kalangan Academicy, Bussiness, Goverment dan Community (ABGC) dalam bentuk skoring.

Validitas dari metode AHP ditentukan oleh kompetensi keypersons sehingga dipilih orang-orang yang kompeten baik secara teoritis maupun praktis.Keyperson dari academicy dipilih akademisi di bidang lingkungan sedangkan keyperson dari bussiness dipilih PT. Batik Keris dan PT. Dan Liris. Keyperson dari Goverment adalah pemerintah daerah Kabupaten Sukoharjo yaitu Badan Perencanaan Pembangunan Daerah (Bappeda), Badan 
Lingkungan Hidup (BLH), Dinas Pekerjaan Umum (DPU), Dinas Perindustrian dan Dinas Koperasi dan UMKM. Community diwakili oleh tokoh masyarakat yaitu Kepala Desa Banaran, Ketua Lembaga Pemberdayaan Masyarakat (LPM), Ketua Badan Perwakilan Desa (BPD) di Desa Banaran dan Lembaga Swadaya Masyarakat (LSM) Lingkungan. Hasil penilaian dari keyperson kemudian diolah menggunakan software Expert Choice 11. dengan output berupa grafik dan skor prioritas starategi.

\section{HASIL DAN DISKUSI}

\subsection{Gambaran Umum}

Desa Banaran Kecamatan Grogol merupakan salah satu wilayah sentra UMKM Batik yang potensial dalam mendukung pertumbuhan ekonomi di Kabupaten Sukoharjo. UMKM Batik dikelola secara konvensional dan merupakan usaha turun temurun dari nenek moyang. Secara geografis Desa Banaran berbatasan langsung dengan wilayah Kecamatan Laweyan Kota Surakartayang merupakan daerah sentra UMKM Batik Kampoeng Batik Laweyan yang dipisahkan oleh Sungai Jenes. Desa Banaran terdiri dari 4 dusun yaitu Dusun Talangan, Dusun Banaran, Dusun Pondongan dan Dusun Ngenden. Memiliki luas 131 Ha dengan komposisi sawah $30 \mathrm{Ha}$, pekarangan $96 \mathrm{Ha}$ dan lainnya $5 \mathrm{Ha}$, dengan jumlah penduduk 8671 jiwa (BPS, 2012).

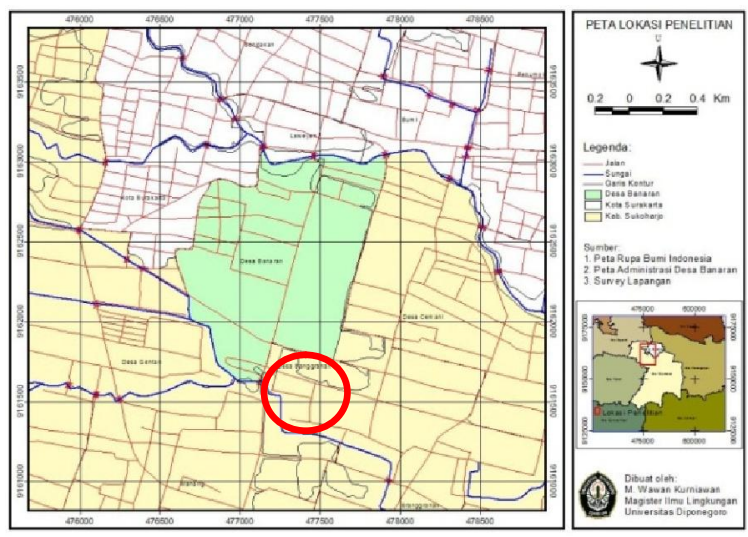

Gambar 1. Peta Lokasi Penelitian
Berdasarkan observasi dan wawancara terhadap UMKM Batik di Desa Banaran, maka didapatkan hasil sebagai berikut:

1. Lokasi UMKM Batik di Desa Banaran terletak secara sporadis dengan distribusi masing-masing di Dusun Ngenden sebanyak 15 UMKM, di Dusun Pondongan sebanyak 3 UMKM dan di Dusun Banaran 2 UMKM.

2. UMKM Batik memiliki jenis produksi batik dan kapasitas produksi yang berbeda. Terdapat 17 pengrajin batik jenis cap, 2 pengrajin batik jenis printing dan 1 pengrajin batik jenis tulis. Debit air limbah yang dihasilkan bervariasi di mana batik jenis cap relatif paling besar dibandingkan jenis printing.

3. UMKM Batik belum menerapkan prinsip Produksi Bersih karena masih menggunakan bahan dan zat warna kimia, tidak melakukan kegiatan reuse, recycle dan recovery (3R) dalam penggunaan sumberdaya maupun energi dalam proses produksi serta membuang air limbah yang mengandung polutan dengan debit yang relatif besar.

4. UMKM Batik memiliki keterbatasan lahan bahkan menggunakan jalan umum untuk menjemur kain bahan batik. Terdapat beberapa lahan kosong antara lain lahan milik pemerintah berupa tanah kas desa salah satunya di bantaran Sungai Jenes.

\subsection{Aspek Teknis}

Aspek teknis meliputi kondisi teknis lokasi, beban pencemaran, sistem dan teknologi IPAL. Berdasarkan kondisi lokasi UMKM Batik di Desa Banaran maka sistem pengolahan air limbah yang sesuai adalah pengolahan air limbah secara komunal terpusat (centralized offsite system). Secara teknis masingmasing UMKM menyalurkan air limbah melalui jaringan perpipaan tertutup menuju IPAL komunal terpusat di lahan yang representatif.

Untuk menentukan sistem dan teknologi pengolahan air limbah UMKM Batik maka diperlukan data mengenai kondisi lahan, kualitas dan kuantitas air limbah yang dihasilkan. Oleh karena hal 
tersebut maka dilakukan pengambilan sampel air limbah pada tanggal 11 Juni 2013 dan diuji di laboratorium yang terakreditasi oleh Komite Akreditasi Nasional (KAN) yaitu Laboratorium Balai Besar Teknik Kesehatan Lingkungan dan
Pemberantasan Penyakit Menular (BBTKL-PPM) Yogyakarta. Hasil uji laboratorium air limbah UMKM Batik adalah sebagai berikut :

Tabel 1. Data Kualitas Air Limbah UMKM Batik

\begin{tabular}{lllccc}
\hline No. & Parameter & Unit & BML & $\begin{array}{c}\text { Batik } \\
\text { Printing }\end{array}$ & $\begin{array}{c}\text { Batik } \\
\text { Cap }\end{array}$ \\
\hline 1. & Temperatur & ${ }^{\circ} \mathrm{C}$ & 38 & 25,1 & 25,0 \\
2. & TSS & $\mathrm{mg} / \mathrm{l}$ & 50 & 151 & 332 \\
3. & BOD & $\mathrm{mg} / \mathrm{l}$ & 60 & 220 & 500 \\
4. & COD & $\mathrm{mg} / \mathrm{l}$ & 150 & 480 & 1.017 \\
5. & Phenol total & $\mathrm{mg} / \mathrm{l}$ & 0,5 & 0,0260 & 0,1178 \\
6. & Khrom total & $\mathrm{mg} / \mathrm{l}$ & 1,0 & $<0,0213$ & $\varangle 0,0213$ \\
7. & Amoniak total & $\mathrm{mg} / \mathrm{l}$ & 8,0 & 13,0125 & 11,8990 \\
8. & Sulfida & $\mathrm{mg} / \mathrm{l}$ & 0,3 & $\mathrm{Ttd}$ & $\mathrm{Ttd}$ \\
9. & Minyak- & $\mathrm{mg} / \mathrm{l}$ & 3,0 & - & - \\
& Lemak & & & & \\
10 & pH & $\mathrm{mg} / \mathrm{l}$ & $6-9$ & 9,0 & 11,3 \\
\hline
\end{tabular}

Sumber :Data Primer, 2013

Dari tabel 1 terlihat bahwa parameter $\mathrm{pH}, \mathrm{BOD}, \mathrm{COD}$, TSS dan Amoniak total melebihi baku mutu lingkungan (BML) berdasarkan Peraturan Daerah Provinsi Jawa Tengah No. 5 Tahun 2012 tentang Baku Mutu Air Limbah Industri Tekstil dan Batik Provinsi Jawa Tengah. Dibutuhkan sistem dan teknologi pengolahan air limbah yang mampu menurunkan kadar bahan pencemar tersebut agar memenuhi baku mutu lingkungan yang ditetapkan.

Beberapa pertimbangan dalam pemilihan teknologi pengolahan air limbah, antara lain: a) Kualitas dan kuantitas air limbah yang akan diolah, b) Kemudahan pengoperasian dan ketersediaan SDM yang memenuhi kualifikasi untuk pengoperasian jenis IPAL terpilih, c) Jumlah akumulasi lumpur, d) Kebutuhan dan ketersediaan lahan, e) Biaya pengoperasian, f) Kualitas hasil olahan yang diharapkan dan g) Kebutuhan energi (PPLP DPU, 2011).

Berdasarkan kuesioner dan wawancara yang dilakukan terhadap 20 responden UMKM Batik dapat disimpulkan bahwa mereka belum memiliki pengetahuan, keahlian dan kemampuan dana yang cukup dalam 66 menyediakan pengolahan air limbah, sehingga pengolahan air limbah yang cocok untuk diterapkan adalah yang memiliki teknologi yang mudah dan biaya operasional serta perawatan yang murah. Masing-masing teknologi memiliki kelebihan dan kekurangan terkait variabel dana, kualitas air limbah dan luas lahan. Diperlukan optimasi dari ketiga variabel tersebut sesuai dengan kondisi teknis, ekonomi dan sosial guna terwujudnya kinerja pengolahan yang baik dan tetap berlangsungnya keberlanjutan pengelolaan air limbah UMKM Batik.

Terdapat banyak teknologi pengolahan air limbah UMKM Batik yang dapat dilakukan untuk menurunkan kadar pencemar sesuai baku mutu yang telah ditetapkan yaitu warna, suhu, $\mathrm{pH}$, BOD, COD, TSS, Phenol total, Amonia total, Minyak-Lemak dan Krom total baik secara fisika, kimia dan biologi. Proses fisika dan kimia cenderung lebih mahal dalam operasional dan menghasilkan lumpur cukup banyak dibandingkan proses biologi.

Berdasarkan hasil uji kualitas air limbah UMKM Batik jenis cap dan printing yang telah dilakukan didapatkan perbandingan nilai BOD/ COD antara 0,40,49 yang berarti lebih besar dari 0,4 
sehingga alternatif proses yang dipilih adalah proses biologi. Jika disyaratkan teknologi yang mudah, biaya yang murah, menghasilkan sedikit lumpur dan pada lahan yang relatif kecil, maka dipilih proses secara anaerob. Alternatif teknologi pengolahan air limbah untuk memenuhi kriteria tersebut yaitu reaktor bersekat secara anaerob atauAnaerobic Baffled Reactor (ABR) danbiofilter tercelup atau Submerged Biofilter anaerob. Kelebihan dari biofilter adalah pengoperasiannya mudah, lumpur yang dihasilkan sedikit, dapat digunakan untuk air limbah konsentrasi rendah maupun tinggi, tahan terhadap fluktuasi debit dan konsentrasi air limbah dan pengaruh penurunan suhu terhadap efisiensi pengolahan kecil, namun kelemahannya memerlukan energi listrik yang cukup besar (Said, 2002).

Untuk mengurangi kadar warna dan logam berat, berbagai penelitian menggunakan mikroorganisme telah dilakukan antara lain menggunakan Lactobacillusdelbrukii (Siti Zuraida, 2013) , Bacillus sp (Siddiqui et. al, 2011, Aspergillus sp dan Brevibacterium casei. Penelitian tentang pengurangan kadar kromat Cr (VI) dan zat warna azo Acid Orange 7 (AO7) menggunakan Brevibacterium casei(Ng., 2010).

Jika disyaratkan proses biologi dengan teknologi yang mudah, dana operasional relatif lebih murah tetapi tersedia lahan yang luas, maka alternatif pengolahan adalah dengan teknologi kolam rawa buatan berupa fitoremediasi atau Wetland. Kelebihan wetland selain dapat menurunkan polutan organik juga dapat menyerap warna dan logam berat.Menurut Tridech et. al., 1981tanaman Eichornia crassipes (enceng gondok) dapat menurunkan kadar BOD sebesar 94,95\%, Total Organic Carbon (TOC) sebesar 80\% dan TSS sebesar 99,2\%, sedangkan tanaman Scirpus dapat menurunkan kadar BOD sebesar 75,78\%, TOC sebesar 66,02\% dan TSS sebesar 94,2\%. Terdapat penelitian tentang kemampuan tanaman rawa berdaun sempit (Typha angustifolia Linn) menunjukkan bahwa dekolorisasi limbah zat warna reaktif oleh tanaman ini sebesar 60\% (Niltratnisakorn, 2010).
Hasil analisis urutan prioritas strategi aspek teknis dalam pengelolaan air limbah UMKM Batik dengan program Expert Choice 11.yaitu :

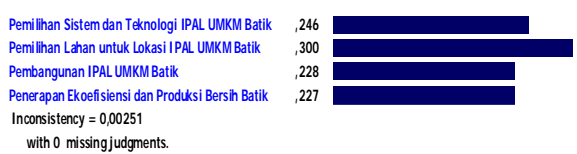

(1) Penentuan lahan untuk lokasi IPAL (skor : 0,300)

(2) Pemilihan sistem dan teknologi IPAL (skor : 0,246)

(3) Pelaksanaan pembangunan IPAL (skor : 0,228)

(4) Penerapan prinsip Produksi Bersih batik $(0,227)$

\subsection{Aspek Ekonomi}

Aspek ekonomi meliputi kondisi ekonomi wilayah, biaya investasi, operasional dan perawatan IPAL dan program CSR swasta.Perekonomian di Desa Banaran ditopang dari kegiatan industri pengolahan dan perdagangan baik oleh usaha skala besar maupun UMKM. Sesuai konsep good corporate governance yang menempatkan sektor swasta sebagai komponen dari good governance maka keberadaannya diharapkan memberikan kontribusi dalam kegiatan pembangunan. Sektor swasta atau perusahaan besar sesuai dengan Undang-Undang RI Nomor 40 Tahun 2007 tentang Perseroan Terbatas tentang Perseroan Terbatas yang diperjelas dengan Peraturan Pemerintah Nomor 47 Tahun 2012 tentang Tanggung Jawab Sosial dan Lingkungan Perseroan Terbatas, memiliki kewajiban melakukan program Corporate Social Responsibility (CSR) atau tanggung jawab sosial dan lingkungan di daerah sekitarnya. Kegiatan CSR dapat dilakukan pada bidang ekonomi, sosial budaya, kesehatan dan lingkungan. Terdapat 8 indikator dalam mengukur kinerja CSR, yaitu kepemimpinan, proporsi bantuan, transparansi dan akuntabilitas, cakupan wilayah, perencanaan dan monitoring serta evaluasi, pelibatan stakeholder, keberlanjutan dan hasil nyata (outcome)(Kartini, 2009).

Perusahaan besar di Desa Banaran adalah PT. Batik Keris yang menghasilkan produk kain dan pakaian batik dan PT. Dan Liris yang 
menghasilkan produk bermacam kain termasuk batik. Berdasarkan hasil observasi dan wawancara yang dilakukan diketahui bahwa program CSR kedua perusahaan belum optimal sesuai standar kriteria program CSR dan regulasi yang ada. Belum terdapat perencanaan dan pelaksanaan program CSR dalam pengelolaan air limbah UMKM Batik di Desa Banaran. Kedua perusahaan ini memiliki potensi dan diharapkan dapat memberikan kontribusi yang besar baik berupa dana maupun teknologi dalam pengelolaan lingkungan khususnya dalam pengelolaan air limbah UMKM Batik di Desa Banaran.

Berdasarkan estimasi perhitungan ekonomi didapatkan biaya investasi IPAL sebesar Rp 3.018.177.701 (periode desain 20 tahun) dan biaya operasional dan perawatan IPAL sebesar Rp 54.327.588 per tahun. Skenario sumber pendanaan dalam investasi, operasional dan perawatan IPAL berasal dari pemerintah, UMKM Batik dan dana program CSR swasta.

Hasil analisis urutan prioritas strategi aspek ekonomi dalam pengelolaan air limbah UMKM Batik dengan program Expert Choice 11. yaitu :

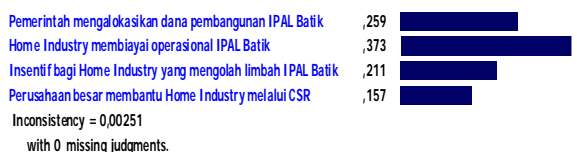

(1) Swadana UMKM Batik untuk operasional dan perawatan IPAL (skor : 0,373)

(2) Alokasi dana pemerintah untuk membangun IPAL (skor : 0,259)

(3) Penerapan insentif dan disinsentif ekonomi (skor : 0,211

(4) Dana program CSR swasta (skor : $0,157)$

\subsection{Aspek Manajemen}

Aspek manajemen meliputi regulasi, kebijakan dan program pemerintah, kelembagaan pemerintah dan kelembagaan UMKM. Regulasi dan kebijakan pemerintah dari tingkat pusat, provinsi dan kabupaten terkait pengelolaan air limbah UMKM Batik dituangkan dalam bentuk undangundang, peraturan pemerintah, keputusan menteri, peraturan daerah dan keputusan kepala daerah, yaitu

Tabel 2. Regulasi terkait Pengelolaan Lingkungan UMKM dalam Perspektif Good Governance.

\begin{tabular}{|c|c|}
\hline Regulasi & Pasal \\
\hline $\begin{array}{l}\text { 1. Undang-Undang RI Nomor } 32 \text { Tahun } 2004 \text { tentang } \\
\text { Pemerintah Daerah }\end{array}$ & $\begin{array}{l}\text { pasal } 1 \text { butir } 5 \text {, pasal } 13 \text { ayat } 1 \text {, } \\
\text { pasal } 14 \text { ayat } 1\end{array}$ \\
\hline $\begin{array}{l}\text { 2. Undang-Undang RI Nomor } 25 \text { Tahun } 2007 \text { tentang } \\
\text { Penanaman Modal }\end{array}$ & $\begin{array}{l}\text { pasal } 15 \text { (b) pasal } 13 \text { ayat } 1 \text {, } \\
\text { pasal } 14 \text { ayat } 1\end{array}$ \\
\hline $\begin{array}{l}\text { 3. Undang-Undang RI Nomor } 26 \text { Tahun } 2007 \text { tentang } \\
\text { Penataan Ruang }\end{array}$ & pasal 2, pasal 3, pasal 25 \\
\hline $\begin{array}{l}\text { 4. Undang-Undang RI Nomor } 40 \text { Tahun } 2007 \text { tentang } \\
\text { Perseroan Terbatas }\end{array}$ & pasal 74 ayat 1 \\
\hline $\begin{array}{l}\text { 5. Undang-Undang RI Nomor } 20 \text { Tahun } 2008 \text { tentang } \\
\text { Usaha Mikro, Kecil dan Menengah }\end{array}$ & $\begin{array}{l}\text { pasal } 2 \text { huruf } f \text {, pasal } 7 \text { ayat } 1 \\
\text { pasal } 16 \text { ayat } 1 \text {, pasal } 20 \text { huruf d }\end{array}$ \\
\hline $\begin{array}{l}\text { 6. Peraturan Pemerintah RI Nomor } 82 \text { Tahun } 2001 \\
\text { tentang Pengelolaan Kualitas Air dan Pengendalian } \\
\text { Pencemaran Air }\end{array}$ & pasal 18, pasal 37 \\
\hline $\begin{array}{l}\text { 7. Peraturan Pemerintah Nomor } 41 \text { Tahun } 2007 \text { tentang } \\
\text { Organisasi Perangkat Daerah }\end{array}$ & pasal 14 \\
\hline $\begin{array}{l}\text { 8. Peraturan Pemerintah RI Nomor } 47 \text { Tahun } 2012 \\
\text { tentang Tanggung Jawab Sosial dan Lingkungan } \\
\text { Perseroan Terbatas }\end{array}$ & pasal 2, pasal 3 \\
\hline $\begin{array}{l}\text { 9. Keputusan Menteri Negara Lingkungan Hidup Nomor } \\
51 \text { Tahun } 1995 \text { tentang Baku Mutu Limbah Cair bagi } \\
\text { Kegiatan Industri }\end{array}$ & $\begin{array}{l}\text { pasal } 2 \text { nomor } 9 \text {, pasal } 6 \text {, } \\
\text { lampiran Baku Mutu untuk } \\
\text { Industri Tekstil }\end{array}$ \\
\hline
\end{tabular}


Berdasarkan berbagai regulasi pusat tersebut secara substansial masingmasing konsiderans maupun isi dalam pasal-pasal tentang kewenangan memiliki nilai-nilai yang mendasarkan bahwa paradigma kebijakan lingkungan hidup harus menjadi mainstream kebijakan di tingkat pemerintah pusat, provinsi dan kabupaten/ kota.

Regulasi pemerintah di tingkat pusat terkait kebijakan lingkungan menjadi basis dalam penyusunan regulasi dan kebijakan di tingkat pemerintah daerah di tingkat Provinsi Jawa Tengah dan Kabupaten Sukoharjo terkait tata ruang, pengelolaan lingkungan dan pengendalian pencemaran, yaitu :

1. Peraturan Daerah Provinsi Jawa Tengah Nomor 5 Tahun 2007 tentang Pengelolaan Lingkungan Hidup.

2. Peraturan Daerah Provinsi Jawa Tengah Nomor 5 Tahun 2012 tentang Perubahan atas Perda Provinsi Nomor 10 Tahun 2004 tentang Baku Mutu Air Limbah.

3. Peraturan Daerah Kabupaten Sukoharjo Nomor 1 Tahun 2008 tentang Urusan Pemerintahan yang Menjadi Kewenangan Pemerintahan Daerah Kabupaten Sukoharjo

4. Peraturan Daerah Kabupaten Sukoharjo Nomor 9 Tahun 2009 tentang Pengendalian Lingkungan Hidup.

5. Peraturan Daerah Kabupaten Sukoharjo Nomor 3 Tahun 2010tentang Rencana Pembangunan Jangka Panjang Daerah Tahun 20052025.

6. Peraturan Daerah Kabupaten Sukoharjo Nomor 1 Tahun 2011 tentang Rencana Pembangunan Jangka Menengah Daerah Tahun 2010-2015.

7. Peraturan Daerah Kabupaten Sukoharjo Nomor 14 Tahun 2011 tentang Rencana Tata Ruang Wilayah Kabupaten Sukoharjo Tahun 20112031.

Berdasarkan kajian terhadap regulasi, kebijakan dan program di Kabupaten Sukoharjo maka dapat disimpulkan bahwa belum terdapat adanya program perencanaan pengelolaan air limbah UMKM Batik di Desa Banaran.
Pemerintah memiliki peran yang strategis melalui instansi terkaitdalam pengelolaan air limbah UMKM Batik. Kelembagaan pemerintah Kabupaten Sukoharjo diatur dalam Peraturan Daerah Kabupaten Sukoharjo Nomor 3 Tahun 2008 tentang Organisasi dan Tata Kerja Dinas Daerah Kabupaten Sukoharjo.

Instansi yang terkait dengan pengelolaan air limbah UMKM Batik di Kabupaten Sukoharjo sesuai peran dan kewenangannya masing-masing yaitu :

1. Badan Perencanaan Pembangunan Daerah (Bappeda)

2. Badan Lingkungan Hidup (BLH)

3. Dinas Pekerjaan Umum (DPU)

4. Dinas Perindustrian

5. Dinas Koperasi dan UMKM

Berdasarkan kajian yang telah dilakukan maka masing-masing instansi, maka dapat disimpulkan perlunya peningkatan kapasitas dan koordinasi yang solid dan intensif sesuai kewenangannya dalam kegiatan proses produksi, pengelolaan air limbah dan kelembagaan UMKM Batik di Desa Banaran.

Hasil analisis urutan prioritas strategi aspek manajemen dalam pengelolaan air limbah UMKM Batik dengan program Expert Choice 11. yaitu :

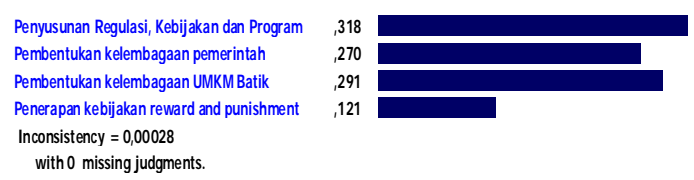

(1) Penyusunan regulasi, kebijakan dan program terkait air limbah UMKM Batik (skor : 0,318)

(2) Pembentukan kelembagaan UMKM Batik (skor : 0,291)

(3) Optimasi kelembagaan pemerintah dalam pengendalian pencemaran (skor : 270)

(4) Penerapan kebijakan reward dan punishment dalam pengendalian pencemaran industri (skor : 0,121)

\subsection{Aspek Sosial}

Aspek sosial meliputi persepsi, sikap dan kesediaan partisipasi UMKM Batik. Kondisi sosial UMKM batik di Desa Banaran memegang peranan yang penting dalam perencanaan pemberdayaan UMKM Batik dalam 
pengelolaan air limbah secara optimal dan berkelanjutan. Pendekatan sosial budaya merupakan salah satu bagian penting untuk memahami karakteristik kehidupan masyarakat khususnya masyarakat UMKM batik di Desa Banaran. Kondisi sosial yang kondusif merupakan good social governance sebagai komponen dari good governance yang sangat penting.

Berdasarkan kuesioner yang diberikan kepada 20 responden UMKM batik di Desa Banaran, maka dapat diketahui UMKM memiliki persepsi bahwa air limbah batik akan mencemari lingkungan dan diperlukan adanya pengolahan terlebih dahulu sebelum dibuang ke lingkungan, namun mereka membutuhkan bantuan pihak luar baik pemerintah maupun swasta berupa program fisik dan non-fisik. Program fisik yaitu pembangunan prasarana dan sarana IPAL komunal, sedangkan nonfisik berupa pembinaan untuk meningkatan pengetahuan, keahlian dan organisasi kelembagaan UMKM batik. Sebagian besar UMKM batik sanggup untuk berpartisipasi melalui iuran rutin secara kolektif dalam membiayai operasional dan perawatan IPAL komunal.

Hasil analisis urutan prioritas strategi aspek sosial dalam pengelolaan air limbah UMKM Batik dengan program Expert Choice 11. yaitu :

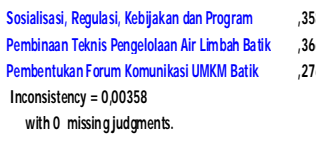

(1) Pembinaan teknis pengelolaan air limbah UMKM Batik (skor : 0,366)

(2) Sosialisasi regulasi, kebijakan dan program terkait air limbah UMKM Batik (skor : 0,356)

(3) Pembentukan forum komunikasi UMKM Batik dengan masyarakat (skor : 0,278)

\subsection{Strategi Kriteria Aspek}

Berdasarkan kajian strategi pada masing-masing aspek, maka menurut program Expert Choice 11. Didapatkan urutan prioritas strategi yaitu:
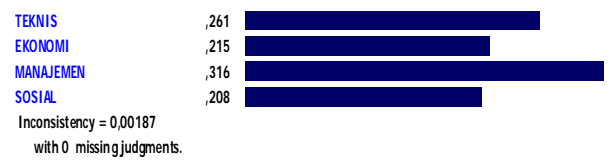

(1) Aspek Manajemen (skor : 0,316)

(2) Aspek Teknis (skor : 0,261)

(3) Aspek Ekonomi (skor : 0,215)

(4) Aspek Sosial (skor : 0,208)

Pada aspek manajemen, komponen yang terlibat adalah pemerintah dan UMKM Batik yang merupakan key stakeholder dalam pengelolaan air limbah UMKM Batik. Pemerintah merupakan regulator yang berperan dalam penyusunan regulasi, kebijakan dan program pemerintah, sehingga akan terwujud legitimasi kegiatan dalam perencanaan, implementasi dan evaluasi serta alokasi dana untuk mewujudkan pengelolaan air limbah UMKM Batik. Selain itu pemerintah juga sebagai fasilitator dalam proses pemberdayaan UMKM Batik dalam pengelolaan air limbah melalui pengembangan sumberdaya manusia, kelembagaan UMKM maupun swadaya UMKM dalam operasional dan perawatan IPAL. Kemitraan antara pemerintah dan UMKM mutlak diperlukan guna terwujudnya pengelolaan air limbah UMKM Batik secara optimal dan berkelanjutan.

\section{KESIMPULAN}

Berdasarkan hasil penelitian yang dilakukan, maka dapat disimpulkan sebagai berikut :

1. Prioritas strategi dalam pengelolaan air limbah UMKM Batik di Desa Banaran pada masing-masing aspek yaitu : (1) Aspek Manajemen : penyusunan regulasi, kebijakan dan program dari pemerintah Kabupaten Sukoharjo secara fokus dan detail dalam mewujudkan pengelolaan air limbah sentra UMKM Batik, (2) Aspek Teknis : penentuan lahan untuk Instalasi Pengolahan Air Limbah (IPAL) komunal terpusat oleh pemerintah dengan teknologi yang mudah, biaya operasional dan perawatan yang murah dengan kinerja hasil pengolahan yang memenuhi baku mutu lingkungan 
yaitu pengolahan secara biologi dengan proses kombinasi anaerobaerob diprakarsai oleh BLH Kabupaten Sukoharjo, (3) Aspek Ekonomi : swadana UMKM Batik dalam operasional dan perawatan IPAL UMKM Batik secara kontinyu dalam operasional dan perawatan IPAL serta pengendalian pencemaran air, (4) Aspek Sosial : pembinaan teknis kepada UMKM Batik dalam pengelolaan air limbah oleh pemerintah bekerjasama dengan perguruan tinggi danLSM.

2. Pengelolaan air limbah UMKM Batik di Desa Banaran secara optimal dan berkelanjutan memerlukan pengkajian, perencanaan, kerjasama dan kemitraan di antara stakeholders dalam pengelolaan air limbah UMKM Batik yaitu pemerintah Kabupaten Sukoharjo melalui instansi terkait, UMKM Batik, masyarakat dan sektor swasta pelaku CSR sebagai perwujudan dari paradigma good governance dalam kerangka pembangunan yang berkelanjutan.

\section{UCAPAN TERIMAKASIH :}

Penulis menyampaikan ucapan terimakasih yang sebesar-besarnya kepada :

1. Pusat Pembinaan Pendidikan dan Pelatihan Perencanaan (Pusbindiklatren) Badan Perencanaan Pembangunan Nasional (Bappenas) atas kesempatan dan beasiswa yang diberikan.

2. Pemerintah Kabupaten Sukoharjo atas ijin yang diberikan kepada penulis selama menempuh tugas belajar di Program Magister Ilmu Lingkungan UNDIP.

\section{REFERENSI}

Abdul Wahid, Zularisam, Sakinah, Mimi, Munaim, Abdul, 2011. Sustainable Technology for Treatment of Batik Waste Effluent, United States Patent 2011/ 007353 A1.

Badan Pusat Statistik, 2012.Kecamatan Grogol dalam Angka Tahun 2012.BPS, Sukoharjo.
Budiati, Lilin, 2012.Good Governance dalam Pengelolaan Lingkungan Hidup.Ghalia Indonesia, Bogor.

Direktorat Pengembangan Penyehatan Lingkungan Permukiman, 2011. Modul-4 Tata Cara Pembangunan Prasarana Air Limbah Rumah Tangga, Dirjen Cipta Karya Kementerian Pekerjaan Umum. Jakarta.

Hadi, Sudharto, P, 2005.Dimensi Lingkungan Perencanaan Pembangunan. Gadjah Mada Press, Yogyakarta.

Isrihetty, S., Wan Zaki, W.S., Saim, Ahmad Hashim, 2009.Batik Wastewater Treatment by Nanoparticle Titanium Dioxide, $\mathrm{TiO}_{2}$. FKEE Compilation of Papers.

Kartini, Dwi, 2009.Corporate Social Responsibility Transformasi Konsep Sustainibility Management dan Implementasi Indonesia. Refika Aditama, Bandung.

Kurniadie, Denny, 2011.Teknologi Pengolahan Limbah Cair secara Biologis. Widya Padjadjaran, Bandung.

Kusumawati, Nita, Wijiastuti, Asri, Rahmadyanti, Erina, 2012.Operating Conditions Optimization on Indonesian Batik Dyes Wastewater Treatment by Fenton Oxidation and Separating Using Ultrafiltration Membrane. Journal of Environmental Science and Enginering A1(2012)672-682.

Muljadi, 2009. Efisiensi Instalasi Pengolahan Limbah Cair Industri Batik Cetak dengan Metode Fisika, Kimia dan Biologi terhadap Penurunan Parameter Pencemar BOD, COD dan Logam Berat Krom (Cr) (Studi Kasus di Desa butulan Makam Haji Sukoharjo), Equilibrium, Vol. 8, No. 1 (2009)7-16.

Niltratnisakorn, S., Thiravetyan, P., Nakbanpote, W. 2009. A Constructed Wetland Model for Synthetic Reactive Dye Wastewater Treatment by Narrow-Leaved Cattails (Typha angustifolia Linn). Water Science Technology. 60, 1565-1574. 
Ng, T.W., Cai, Q., Wong, C-K, Chow, A.T., Wong, P-K, 2010. Simultaneous Chromate Reduction and Azo Dye Decolorization by Brevibacterium casei : Azo dye as donor for chromate reduction. Jurnal Hazard Mater, 182, 792-800.

Nugroho, Rudi dan Ikbal, 2005.Kinetika Proses AOPs untuk Penghilangan Warna Air Limbah Produksi Batik. JAI, Vol. 1, No. 3.

Rahardjo, P. Nugroho, 2008.Kajian Aspek Kebijakan dan Regulasi dalam Masalah Pengelolaan Limbah Cair Industri Rumah Tangga. JAI Vol. 4, No. 2.

Rashidi, H.R., Nik Sulaiman, N.M., Hashim, NA., 2012.Batik industry synthetic wastewater treatment using nanofiltrattion membrane.Procedia Engineering 44 (2012) 2010-2012.

Said, Nusa Idaman, 2002.Pengolahan Air Limbah IKM Tekstil dengan Proses Biofilter Aaerob-Aerob Tercelup Menggunakan Media Plastik Sarang Tawon, Jurnal Teknologi Lingkunga., Vol. 2, No. 2, Mei 2002, Hal. 124-135.
Satrawijaya, A. Tresna, 2009.Pencemaran Lingkungan, Rineka Cipta, Jakarta.

Siddiqui, M.F., Wahid, Z.A., Sakinah, M., 2011. Bioremediation and Biofouling Perspektive of Real Batik Effluent by Indigenous Bacteria. International Journal of Chemical and Environmental Engeneering, Vol 2 No 5.

Siti Zuraida, M., Nurhaslina, C.R., Ku Halim, K.H., 2013.Influence of Agitation, $\mathrm{pH}$, and Temperatur on Growth and Decolorization of Batik Wastewater by Bacteria Lactobacillus Delbruckii. IJRRAS 14 (2).

Subki, Noor Syuhadah and Rohasliney, H., 2011.A Preliminary Study on Batik Effluent in Kelantan State: A Water Quality Perspectiv., International Conference on Chemical, Biological and Environment Science (ICCEBS'2011). 